\title{
EVALUATION OF FUNCTIONING AND STATUS OF IMPLEMENTATION OF HEMOVIGILANCE PROGRAM OF INDIA IN THE BLOOD BANKS OF SOUTHERN KERALA
}

\author{
SREEKUMAR PK ${ }^{1 *}$, PRAMOD KUMAR TM², PARTHA SARATHI G², DEBASISH GUPTA ${ }^{3}$, Pallavi Prakash ${ }^{4}$ \\ ${ }^{1}$ Assistant Drugs Controller, Office of the Assistant Drugs Controller, Thiruvananthapuram, Kerala, India. ${ }^{2}$ Department of Pharmacy, \\ Jagadguru Sri Shivarathreeswara University, Mysore, Karnataka, India. ${ }^{3}$ Department of Transfusion Medicine, Sri Chitra Tirunal Institute \\ for Medical Sciences and Technology, Thiruvananthapuram, Kerala, India. ${ }^{4}$ Department of Transfusion Medicine, JSS Hospital, Mysore, \\ Karnataka, India. Email: skumardi@gmail.com
}

Received: 10 September 2017, Revised and Accepted: 01 November 2017

\section{ABSTRACT}

Objective: The objective of this study is to evaluate the functioning and status of implementation of hemovigilance program of India (HvPI) in the blood banks of southern Kerala.

Methods: It was a survey approach to analyze the facilities, working nature, and status of implementation of hemovigilance program by the blood banks located in the three districts of southern Kerala. Both goevrnment and private sector blood banks were subjected to the survey. Standard pro forma was used to collect the data. Collected data were analyzed by percentages and ratios.

Results: A total of 40 blood banks were covered in the study. All the blood banks were licensed for handling whole blood. 23 blood banks were licensed for handling blood components. 6 blood banks process $100 \%$ blood into components. Majority of blood banks have excellent demand for components. Packed red cells, platelet concentrate, and fresh frozen plasma were the significant components among the prepared components. Majority of the blood banks under the survey had hospital transfusion committee (HTC). 25 blood banks replied as the HvPI is an excellent/good system. However, only 11 blood banks were enrolled in the HvPI. Training programs for the resident doctors and nurses regarding with adverse transfusion reaction and their reporting were not conducted by 17 blood banks.

Conclusion: Except very few blood banks, all are need more awareness and training programs. Attention should be given in the area such as underreporting, poor implementation of hemovigilance, only serious reactions reporting, and avoiding minor reactions. Core factor is proper functioning of HTC and awareness programs about hemovigilance system.

Keywords: Functioning, Hemovigilance program of India implementation, Blood banks.

(c) 2018 The Authors. Published by Innovare Academic Sciences Pvt Ltd. This is an open access article under the CC BY license (http://creativecommons. org/licenses/by/4. 0/) DOI: http://dx.doi.org/10.22159/ajpcr.2018.v11i2.22479

\section{INTRODUCTION}

Transfusion of blood and blood components is one of the important aspects of modern therapeutics [1-3]. Collection and issue of blood and its components are the general responsibilities of blood banks. However, nowadays, they have some additional challenges and responsibilities, importantly, hemovigilance measures have to be organized, hospital transfusion committees (HTCs) are desirable, and quality systems are needed [4].

Initially, awareness on blood safety was developed at the end of 1980s due to the transmission of infection by transfusion that leads to organizing the hemovigilance system in 1991 at France with the arrangement of monitoring systems by transfusion committees, resulting in a national hemovigilance network in 1994 [5]. The hemovigilance is defined as a set of surveillance procedures covering the whole transfusion chain from the collection of blood and its components up to the follow-up of its recipients intended to collect and assess information on adverse effects, resulting from the use of blood products and to prevent their occurrence or recurrence. Hemovigilance program of India (HvPI) was launched on $10^{\text {th }}$ December 2012. It is a centralized, well-structured program for monitoring adverse reactions associated with transfusion of blood and administration of blood products [6-9].

The vein-to-vein concept is the key factor in transfusion medicine. It covers the entire transfusion chain, that stretching from donor to recipient, and also covers the production as well as usage segment. Due to this multistep involvement of staffs of different departments, it is of prime importance to ensure the quality and safety of transfusion in the hospital. To comply with these standard requirements, the hospitals must develop proper strategies. However, in India, the blood usage system is different compared with other developed countries. The need of HTC was come into focus in 2002 when national blood policy was established. One of the main objectives of the National Blood Policy is "to encourage appropriate clinical use of blood and its products." It was suggested that every institution having a blood transfusion department should comprise HTC and its role was detailed [5].

According to the World Health Organization, "A transfusion committee should be establishing in each hospital to implement the national policy and guidelines and monitor the use of blood and blood products at the local level." Obviously, the HTC plays an important role in promoting safety, efficacy, and efficiency of transfusion services. It is a multidisciplinary team and involves all departments in the hospital that are involved in providing and prescribing blood and blood products. The members of HTC include medical superintendent of hospital as the chairperson, representatives from medicine, surgery, obstetrics, gynecology, orthopedics, and nursing superintendent as members. The convener of the committee is the head from transfusion medicine department. The HTC sets appropriate policies and procedures, reviews and revise them, and monitors practice against them $[5,10-12]$.

In the present study, it was decided to evaluate the functioning and status of implementation of HvPI in the blood banks of southern Kerala, an attempt to provide a direction for further research. 


\section{METHODS}

In the present study, a survey was done to analyze the facilities, working nature, and status of implementation of hemovigilance program by the blood banks located in the three districts of southern Kerala, namely, Thiruvananthapuram, Kollam, and Pathanamthitta. A total of 40 blood banks were covered in the study. A standard pro forma prepared with the guidance of an expert team of doctors in the field of transfusion medicine was used to collect the data which is presented in Table 1. Collected data were analyzed by percentages and ratios.

\section{RESULTS AND DISCUSSIONS}

A total of 40 blood banks of both public and private sectors were covered during the study period which is presented in Table 2.

Analysis of blood products handled by these blood banks revealed that all the blood banks under the study were licensed for handling the whole blood. 23 of 40 blood banks were licensed for handling blood components which include 5 blood banks possess the apheresis facility also. The results of analysis of the percentage of blood processed in to components by subject blood banks were shown in Table 3 and Fig. 1. It was found that only six blood banks (26.08\%) process $100 \%$ blood into components. This study suggests that the clinicians are to be made aware about the advantages of components and optimal blood use as the blood is scares. This can be ensured by the proper implementation of hemovigilance program.
The responses of blood banks regarding with demand of components in own clinical facility are shown in Table 4 and Fig. 2.

The response of blood banks regarding with demand of components is excellent/good in the case of 33 blood banks (82.5\%), of which 23 blood banks have the components facility. Fair demand is expressed by $4(10 \%)$ blood banks, of which 2 blood banks have no component facilities. The poor demand of components for the clinical facility is expressed by $3(7.5 \%)$ blood banks, and 7 blood banks have the need for whole blood only.

Types of blood components prepared by blood banks under the study are shown in Table 5 and Fig. 3. Ideally, processing of blood into its components is more advantageous to patients because they receive only their exact need. Moreover, the adverse reaction rate can be reduced by issuing components. Creating the awareness about the advantages of components among the clinicians may increase the demand of components. HTC must be effective. Only the active HTC can report and follow-up the actions properly. Importantly, clinicians are to be trained and made aware about the importance of hemovigilance program. However, there is also a chance of misinformation from the side of participants.

Majority of the study subjects (92.5\%) have HTC. It is evident that HTC is not constituted in 3 blood banks. $95 \%$ of blood banks reports that adverse transfusion reactions are not reported to the blood bank from

Table 1: Pro forma used for the collection of data

\begin{tabular}{|c|c|}
\hline Question & Response \\
\hline Whether blood bank is licensed for & Whole blood/components/apheresis \\
\hline \multicolumn{2}{|l|}{ What percentage of blood is processed in to components } \\
\hline What is the demand of your component by your clinical facility & Excellent/good/fair/poor \\
\hline Which components are being prepared in your blood bank & $\begin{array}{l}\text { Whole blood/packed red cells/washed red cells/leukodepleted red } \\
\text { cells/irradiated red cells/single donor platelets/platelet concentrate/ } \\
\text { platelet-rich plasma/fresh frozen plasma/cryoprecipitate/cryo-poor } \\
\text { plasma }\end{array}$ \\
\hline $\begin{array}{l}\text { Does adverse transfusion reaction are reported to the blood } \\
\text { bank from the clinical wards }\end{array}$ & Yes/no \\
\hline Do you know about the HvPI & Yes/no \\
\hline Have your blood bank enrolled in the HvPI & Yes/no \\
\hline If yes, do you report regularly & Yes/no \\
\hline If no, what is the reason for not enrolling & $\begin{array}{l}\text { Not aware/fear of any punitive action/procedure not known/no system } \\
\text { for adverse reaction reporting in the hospital/not interested }\end{array}$ \\
\hline Are you planning to enroll yourself to HvPI & Yes/no \\
\hline $\begin{array}{l}\text { What are your views on reporting of Adverse transfusion } \\
\text { reaction }\end{array}$ & Yes/no \\
\hline What are your views on reporting adverse donor reactions & Yes/no \\
\hline $\begin{array}{l}\text { Are you maintaining documents of adverse donor } \\
\text { reactions (In-house/Camps) }\end{array}$ & Yes/no \\
\hline $\begin{array}{l}\text { Do you have SOP manual on investigation and management of } \\
\text { adverse donor reactions }\end{array}$ & Yes/no \\
\hline $\begin{array}{l}\text { Do you have SOP manual on investigation and management of } \\
\text { adverse transfusion reaction }\end{array}$ & Yes/no \\
\hline $\begin{array}{l}\text { If yes, do you discuss the reports of adverse transfusion } \\
\text { reactions in the HTC }\end{array}$ & Yes/no \\
\hline $\begin{array}{l}\text { Have you conducted any training program for the resident } \\
\text { doctors and nurses for adverse transfusion reaction and their } \\
\text { reporting }\end{array}$ & Yes/no \\
\hline Your view points on the overall HvPI & Excellent/good/fair/poor \\
\hline HvPI should be & Voluntary reporting/mandatory reporting \\
\hline Program should have uniform pattern of reporting of reaction & Yes/no \\
\hline Program should not have any legal issues & Yes/no \\
\hline Program should not have any conflict of interest & Yes/no \\
\hline Name and address of blood bank & \\
\hline
\end{tabular}

HTC: Hospital transfusion committee, CME: Continuing medical education, SOP: Standard operating procedure, HvPI: Hemovigilance program of India 
Table 2: Distribution of blood banks selected for the study

\begin{tabular}{|c|c|c|c|c|c|}
\hline $\begin{array}{l}\text { Private Medical College } \\
\text { blood banks }\end{array}$ & Government Medical College blood banks & $\begin{array}{l}\text { Other Government Hospital } \\
\text { blood banks }\end{array}$ & Institutes & Corporate & Total \\
\hline 9 & 2 & 5 & 2 & 22 & 40 \\
\hline
\end{tabular}

Table 3: Percentage of blood processed into components by blood banks under study

\begin{tabular}{lll}
\hline $\begin{array}{l}\text { Percentage of } \\
\text { blood processed } \\
\text { into components }\end{array}$ & $\begin{array}{l}\text { Number of } \\
\text { blood banks }\end{array}$ & $\begin{array}{l}\text { Percentage of } \\
\text { blood banks }\end{array}$ \\
\hline 100 & 6 & 26.08 \\
$90-99$ & 10 & 43.00 \\
$80-89$ & 2 & 08.70 \\
$70-79$ & 2 & 08.70 \\
$60-69$ & 1 & 04.34 \\
$20-29$ & 1 & 04.34 \\
$10-19$ & 1 & 04.34 \\
\hline
\end{tabular}

Table 4: Response of blood banks regarding with demand of components in own clinical facility

\begin{tabular}{ll}
\hline $\begin{array}{l}\text { Response of blood banks regarding with } \\
\text { demand of components for the clinical } \\
\text { facility }\end{array}$ & $\begin{array}{l}\text { Number of } \\
\text { blood bank (\%) }\end{array}$ \\
\hline Excellent & $16(40)$ \\
Good & $17(42.5)$ \\
Fair & $4(10)$ \\
Poor & $3(7.5)$ \\
\hline
\end{tabular}

Table 5: Types of blood components prepared by blood banks under the study

\begin{tabular}{lll}
\hline $\begin{array}{l}\text { Types of blood } \\
\text { components prepared }\end{array}$ & $\begin{array}{l}\text { Number of } \\
\text { blood banks }\end{array}$ & $\begin{array}{l}\text { Percentage of } \\
\text { blood bank (\%) }\end{array}$ \\
\hline Packed red cells & 23 & 100 \\
Washed red cells & 5 & 21.74 \\
Leukodepleted red cells & 5 & 21.74 \\
Irradiated red cells & 1 & 04.35 \\
Single donor platelets & 8 & 34.78 \\
Platelet concentrate & 23 & 100 \\
Platelet-rich plasma & 14 & 60.87 \\
Fresh frozen plasma/ & 23 & 100 \\
Cryoprecipitate & 15 & 65.22 \\
\hline
\end{tabular}

the clinical wards. This indicates that HTC is not functioning properly even though it is formed. If there is any underreporting or reporting of serious reactions only, it reflects the poor implementation of hemovigilance. In every country, it is mandatory that HTC is to ensure reporting of transfusion reactions.

In the present study, it was found that $17 \%$ of the blood banks still do not have the knowledge on HvPI. This indicates the need for awareness programs. The next three questions regarding with HvPI received a mixed responses from the participants. The questions and the replies of participants are shown in Fig. 4 and Table 6.

Only 11 blood banks (27.5\%) were enrolled in the HvPI. Of this, 3 blood banks were not reporting properly. Moreover, 20 blood banks were not familiar to the procedure for enrollment, and one expressed that it was due to the fear of punitive action. One blood bank did not enroll in the program due to the unavailability of system for the reporting of adverse reaction in the hospital. 4 blood banks $(10 \%)$ were not planning to

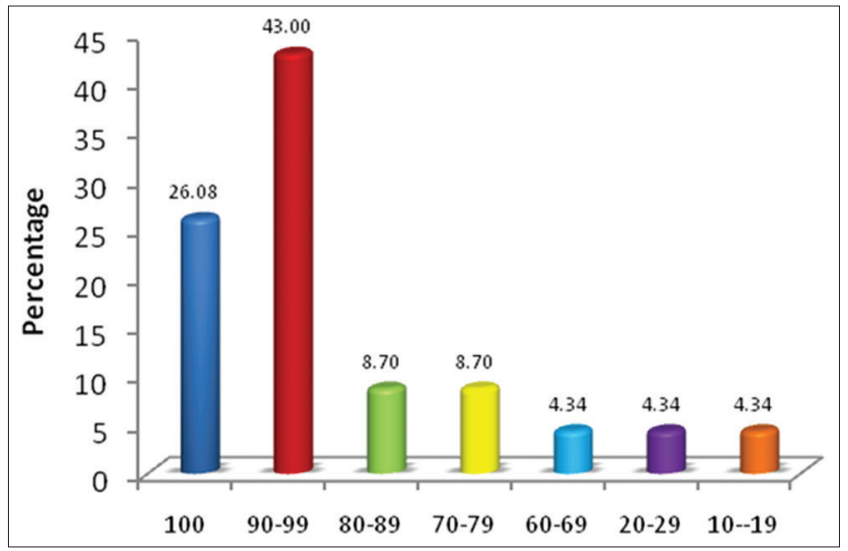

Fig. 1: Percentage of blood processed in to components by blood banks under the study

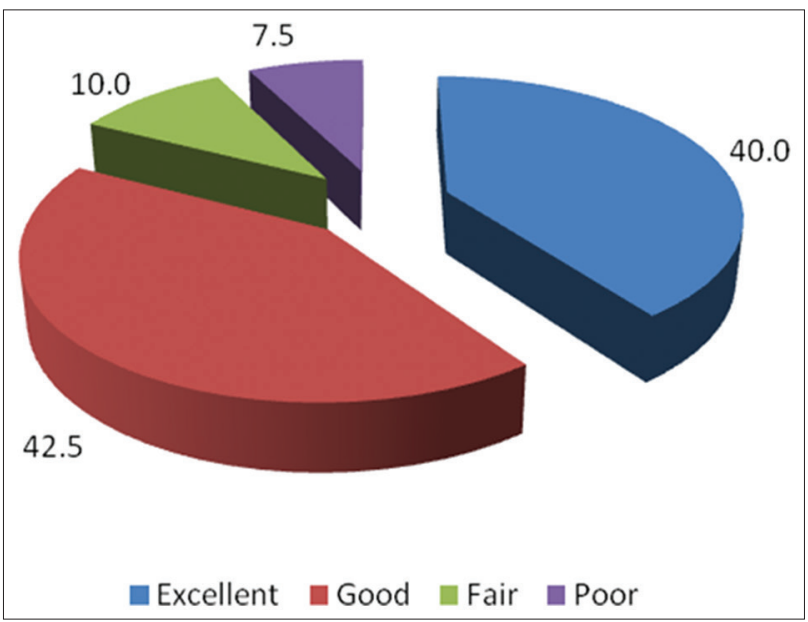

Fig. 2: Response of blood banks regarding with demand of components in own clinical facility

enroll in this program that indicates the need of more awareness and training program in this regard.

The question "what are your views on reporting of adverse transfusion reaction" was received a different type of replies from participating blood banks which are presented in Table 7 and Fig. 5. The results showed that documents of adverse transfusion and donor reactions, standard operating procedures (SOP) manual for investigation, and management of adverse transfusion and donor reactions were not maintained by some of the blood banks. Training programs for the resident doctors and nurses regarding with adverse transfusion reaction and their reporting were not conducted by 17 blood banks (42.5\%), which indicates that more awareness programs and training are needed in this regard.

Various initiatives such as time management in reporting to blood bank, complete investigation for identifying the preventive measures, SOP preparation, and training programs should discuss in the HTC. Such initiatives may helpful to identify and prevent adverse transfusion reactions and make blood transfusion safer. Importantly, reporting should be prompt and adverse reactions need to be investigated. 
Table 6: Responses of participants regarding with HvPI

\begin{tabular}{lll}
\hline Question & Response received & Number of blood banks (\%) \\
\hline Have your blood bank enrolled in HvPI & Yes & $11(27.5)$ \\
& No & $29(72.5)$ \\
If "yes" do you report regularly to HvPI & Yes & $8(20)$ \\
& No & $32(80)$ \\
If "no" what is the reason for not enrolling to HvPI & Not aware & $8(20)$ \\
& Procedure not known & $21(52.5)$ \\
& Fear of any punitive action & $1(2.5)$ \\
& No system of adverse reaction reporting in the hospital & $1(2.5)$ \\
Are you planning to enroll yourself to HvPI & Not interested & Nil (0) \\
& Yes & $36(90)$ \\
\hline
\end{tabular}

HvPI: Hemovigilance Program of India

Table 7: Questions and replies of blood banks regarding with adverse transfusion reaction

\begin{tabular}{|c|c|c|}
\hline Questions & Replies & Number of blood banks (\%) \\
\hline \multirow{2}{*}{$\begin{array}{l}\text { Are you maintaining documents of adverse donor reactions (In-house/ } \\
\text { Camps) }\end{array}$} & Yes & $38(95)$ \\
\hline & No & $2(5)$ \\
\hline \multirow{2}{*}{$\begin{array}{l}\text { Do you have a SOP manual on investigation and management of adverse } \\
\text { donor reactions? }\end{array}$} & Yes & 38 (95) \\
\hline & No & $2(5)$ \\
\hline $\begin{array}{l}\text { Do you have a SOP manual on investigation and management of adverse } \\
\text { transfusion reaction? }\end{array}$ & No & Nil (0) \\
\hline \multirow{2}{*}{$\begin{array}{l}\text { If yes, do you discuss the reports of adverse transfusion reactions in the } \\
\text { HTC? }\end{array}$} & Yes & $37(92.5)$ \\
\hline & No & $3(7.5)$ \\
\hline \multirow{2}{*}{$\begin{array}{l}\text { Have you conducted any training program for the resident doctors and } \\
\text { nurses for adverse transfusion reaction and their reporting? }\end{array}$} & Yes & $23(57.5)$ \\
\hline & No & $17(42.5)$ \\
\hline
\end{tabular}

SOP: Standard operating procedure, HTC: Hospital transfusion committee

Table 8: Questions and replies of blood banks regarding with HvPI

\begin{tabular}{|c|c|c|}
\hline Questions & Replies & Number of blood banks (\%) \\
\hline \multirow[t]{4}{*}{ Your view points on the overall HvPI } & Excellent & $10(25)$ \\
\hline & Good & $15(37.5)$ \\
\hline & Fair & $11(27.5)$ \\
\hline & Poor & $4(10)$ \\
\hline \multirow[t]{2}{*}{ HvPI should be } & Voluntary reporting & $21(52.5)$ \\
\hline & Mandatory reporting & $19(47.5)$ \\
\hline Regular National CME should be done for the program & Yes & $36(90)$ \\
\hline \multirow[t]{2}{*}{ Program should be non-punitive } & Yes & $35(87.5)$ \\
\hline & No & $5(12.5)$ \\
\hline \multirow[t]{2}{*}{ Program should have uniform pattern of reporting of reaction } & Yes & $39(97.5)$ \\
\hline & No & $1(2.5)$ \\
\hline \multirow[t]{2}{*}{ Program should not have any legal issues } & Yes & $35(87.5)$ \\
\hline & No & $5(12.5)$ \\
\hline \multirow[t]{2}{*}{ Program should not have any conflict of interest } & Yes & $38(95)$ \\
\hline & No & $2(5)$ \\
\hline
\end{tabular}

HvPI: Hemovigilance Program of India

With the help of these steps,

- Quality of patients transfusion care can be improved. At the same time, unwanted transfusion can be prevented.

- Reasons for adverse reactions can be identify and possible to prevent in the future.

- National wide data comparison is possible.

Regarding with adverse donor reaction reporting system, it is an excellent initiative to identify and prevent adverse donor reactions and make blood donation safer and pleasant. Adverse donor reaction reporting throws light to the different unreported causes of donor reactions. It should be mandatory and must report because the satisfied donors have a major role in transfusion. Attention in the area such as donor education, motivation, recruiting of voluntary donors, creating pleasant and friendly atmosphere, management of donor reactions according to SOP, social workers, transfusion committee, and media may give better improvements.

Diverse views of blood banks were collected regarding with the HvPI. From the views of blood banks, generally, it can be concluded that HvPI 


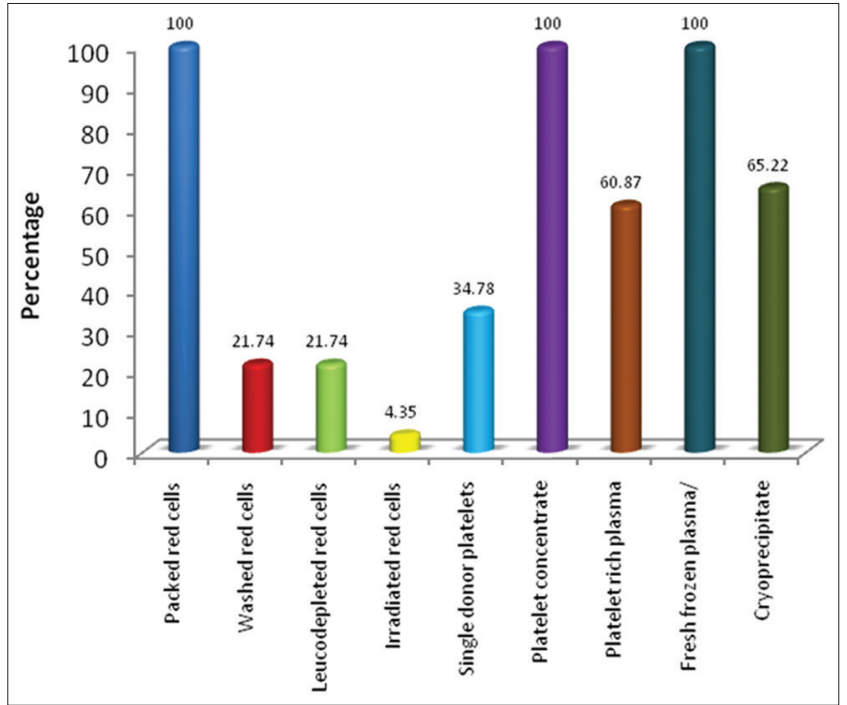

Fig. 3: Types of blood components prepared by blood banks under the study

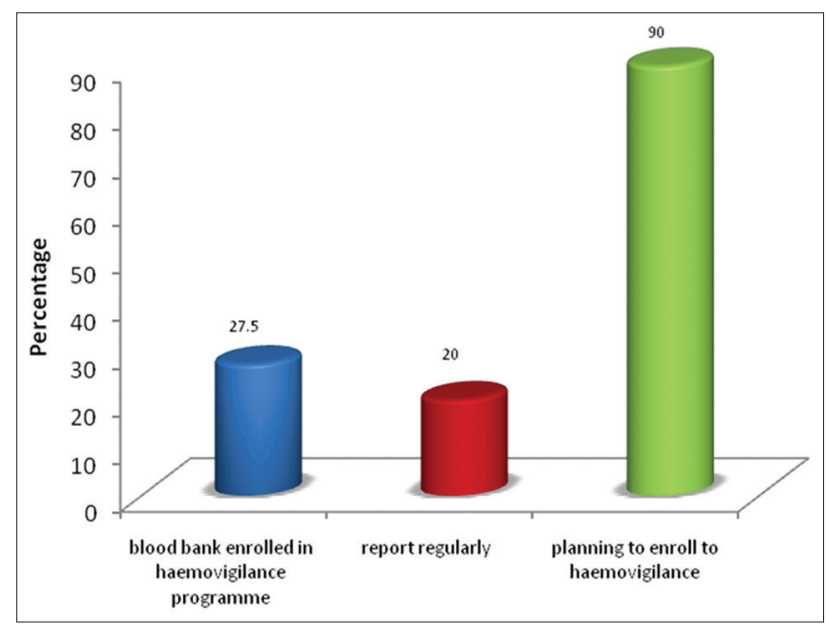

Fig. 4: Responses of participants regarding with hemovigilance program of India

is an excellent initiative to identify and prevent adverse transfusion reactions and donor reactions and make blood transfusion safer. The reports collected from the blood banks are presented in Table 8. It showed that $62 \%$ of the blood banks have expressed that the HvPI is excellent/good. $52.5 \%$ of the blood banks have the opinion that the reporting should be voluntary and almost equally. $47.5 \%$ expressed that the program should be mandatory. Majority of the blood banks expressed that the program should have a uniform pattern of reporting of reaction and should not have any legal issues and conflict of interest. However, only 11 of $40(27.5 \%)$ study subjects were enrolled with HvPI and only 8 among them properly reports to the hemovigilance system.

Ultimately, the challenge for improving the safety of transfusion chain rests primarily in designing and implementing systems that enhance the oversight of transfusion practices and seek to optimize patient safety and efficient utilization of a scarce resource [9]. The results of the present study showed that majority of the blood banks have a better demand for the blood components. Various types of blood components such as packed red cells, washed red cells, leukodepleted red cells, irradiated red cells, single donor platelets, platelet concentrate, platelet-rich plasma, fresh frozen plasma, cryoprecipitate, and fresh/liquid plasma (cryo-poor plasma) are available in these blood banks. However, the availability of products differed among the

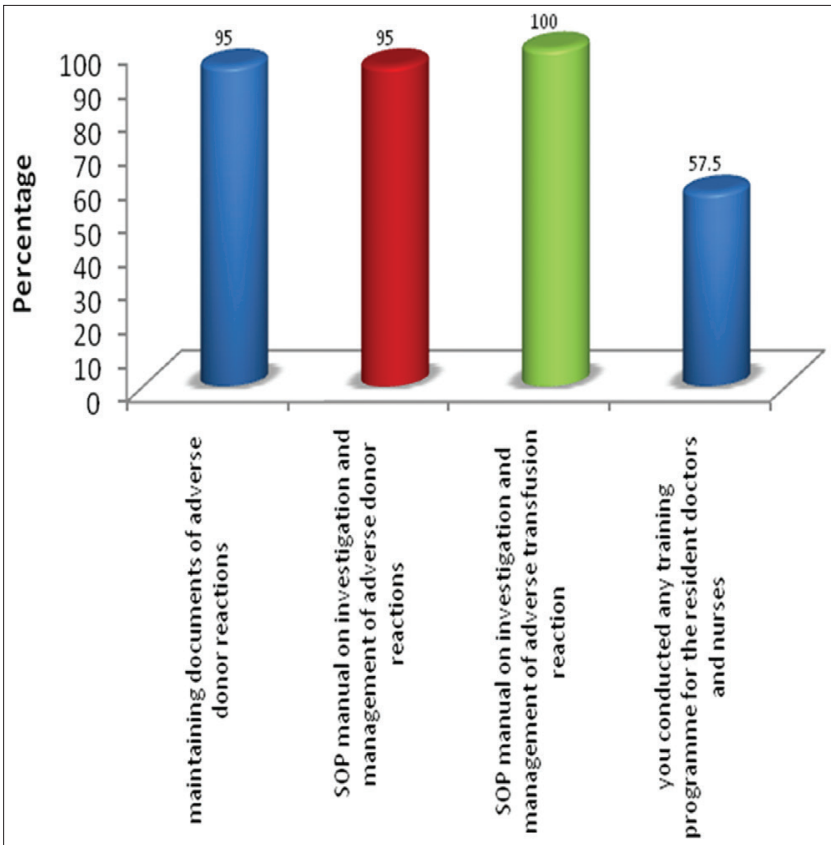

Fig. 5: Questions and replies of blood banks regarding with adverse transfusion reaction

blood banks. Except 3 of 40 study subjects, all are having HTC but not properly reported the adverse transfusion reactions to the blood bank from the clinical wards. However, only 11 of 40 study subjects were enrolled with HvPI and only 8 among them properly reported to the hemovigilance system. However, most of them accepted that it is a valuable system even they have different opinions about the various aspects of this program.

\section{CONCLUSION}

The present study indicated various import steps requiring immediate attention. They are as follows

- Local policies and guidelines should develop at the institutional level based on national guidelines.

- Different aspects of transfusion chain such as indications, contraindications, transfusion triggers, dosage, technical aspects, blood alternatives, and documentation should becovered. Safety aspects of blood transfusion such as identification of patient samples, bedside checks, post-transfusion follow-up, and measures in case of an adverse reaction should also be included.

- Education to the end users may fill the gap in medical education pertaining to transfusion medicine. Interactive training programs, printed education materials are beneficial one in this regard. In such sessions, a pre- and post-training assessment of participants pertaining to their knowledge related to safe transfusion practice may useful.

- Encouraging the staff to report each and every adverse event related to transfusion is essential one.

- Prime importance should be given to join with hemovigilance program of India. The program should be mandatory, then only all the blood banks would be enrolled with the program.

- Implementation of newer technology like leukoreduction to reduce the FNHTR, irradiation in the case of transplantation is the results of proper hemovigilance system. It should be non-punitive, and blood banks should be convinced that the data are used only for assessment and improvement of transfusion practices.

- HTC should ensure mandatory reporting of transfusion reactions. Attention should be given in the area such as underreporting, poor implementation of hemovigilance, only serious reactions reporting, and avoiding minor reactions.

- Core factor is proper functioning of HTC and awareness programs about hemovigilance system. 


\section{ACKNOWLEDGMENT}

The authors would like to thank Mr. J. Kumaran, M. Pharm., (Pharmaceutical Biotechnology), for his assistance in the preparation of this manuscript.

\section{REFERENCES}

1. Mosegui GB, De Mello Vianna CM, Costa e Silva FV, Da Silva Rodrigues MP, Fernandes RR, Do Valle PM, et al. Methods aimed at reducing the residual risk of pathogen transmission during platelet transfusion: A literature review. Int J Pharm Pharm Sci 2016;8:322-9.

2. Veni RK, Devi PB, Romauld SI. A review on artificial blood: A source we need. Asian J Pharm Clin Res 2017;10:38-43.

3. Devarshi S, James S, Najafzadeh E, Pawar S, Kalrao V, Bafna V. Assessment of quality of life, complications and post-transfusion adverse reactions in thalassemia pediatric in tertiary care hospital. Int $\mathrm{J}$ Pharm Pharm Sci 2016;8:317-23.

4. Kaur G, Kaur P. Hospital transfusion committee: Role and responsibilities. Indian J Pathol Microbiol 2014;57:352-4.

5. Mukherjee S, Maiti R. Haemovigilance: A Current update in Indian perspective. J Clin Diagn Res 2016;10:EE05-9.

6. Sreekumar PK, Pramod Kumar TM, Sarathi GP, Gupta D, Prakash P. Haemovigilance and its significance in transfusion safety. Int J Drug Res Tech 2016;6:245-9.

7. Sreekumar PK, Kumar TM, Sarathi GP, Gupta D, Prakash P. Haemovigilance in India-a milestone in transfusion safety. Int J Health Sci Res 2017;7:310-5

8. Sreekumar PK, Kumar TM, Sarathi GP, Gupta D, Prakash P. Haemovigilance-roles and global status in transfusion safety: A Review. Int Res J Pharm 2016;7:5-7.

9. Sreekumar PK, Kumar TM, Sarathi GP, Gupta D, Prakash P. Retrospective evaluation of adverse reactions associated with blood transfusions reported in the blood banks of Kerala. J Med Sci Clin Res 2017;5:18819-24.

10. Haynes SL, Torella F. The role of hospital transfusion committees in blood product conservation. Transfus Med Rev 2004;18:93-104.

11. d'Onofrio G, Bianchi M, Cambieri A, Fiore A, Pupella S, Grazzini G. Hospital transfusion committees: Their role in haemovigilance. Blood Transfus 2009;7 Suppl.1:LE07.

12. James RM, Brown S, Parapia LA, Williams AT. The impact of a 10-year audit cycle on blood usage in a district general hospital. Transfus Med 2001;11:371-5. 